$\xi=-$ 国

\title{
Engenieering Technology in Plastic Biodegradation by Large Bee Moth Larvae Depends on the Type of Polyethylene
}

\author{
Anna V. Vasileva ${ }^{1}$, Iana V. Medvedeva ${ }^{1}$, Nadezhda M. Kostyukova $^{2}$, Malik N. Mukminov ${ }^{1}$, Eduard A. Shuralev ${ }^{1}$ \\ ${ }^{1}$ Kazan Federal University, Institute of Environmental Sciences, 18 Kremlyovskaya St., Kazan, 420008, Russian Federation \\ ${ }^{2}$ Lobachevsky Lyceum of Kazan Federal University, 2/18 Rakhmatullina St., Kazan, 420111, Russian Federation \\ *Corresponding author E-mail: malik-bee@mail.ru
}

\begin{abstract}
The objective of this research was to evaluate the processes of biodegradation of different types of polyethylene by G. mellonella larvae. The determination of the types of polyethylene samples was carried out by IR Fourier spectrometry. The structure of solid household waste includes polyethylene of different types. When assessing the degree of biodegradation, it was found that holes in the polyethylene samples of different sizes formed 5.3 $2.4-28.7 \pm 9.4$ units/day and $54.8 \pm 12.6-1867.8 \pm 38.6 \mathrm{~mm}^{2} /$ day, and the mass of polyethylene samples, depending on the type, decreased on average by $1.5 \pm 0.5-51.0 \pm 6.5 \mu \mathrm{g} /$ day. The obtained results of survival, mobility, weight gain and melanization indicate the absence of negative health effects on larvae when eating polyethylene.
\end{abstract}

Keywords: large bee moth; Galleria mellonella; polyethylene; biodegradation; IR Fourier spectroscopy.

\section{Introduction}

One of the most urgent environmental problems in the modern world is the growth of production and consumption waste: up to $98 \%$ of the materials involved in industrial production become waste. The growth of consumer goods is accompanied by an increase in the amount of household waste that has a negative impact on the environment and organisms [1,2]. According to the UN report 2015, about two billion tons of solid domestic waste is generated on our planet annually. Polymers occupy a relatively small place in the structure of solid domestic waste, but it is plastics based on synthetic polymers that create global environmental problems caused by their stability and prolonged decomposition in the environment [3].

Polyethylene, used for the production of packages, bags, films, is a common type of solid domestic waste, presented in two forms:

- high density polyethylene, or low-pressure polyethylene (HDPE), - low density polyethylene, or high-pressure polyethylene (LDPE). The main ways to recycle solid household waste are to be buried in specially equipped landfills and incineration. Wastes of polymers, including packaging materials, are either buried in the ground or recycled by one of the methods: burning, pyrolysis, hydrolysis, glycolysis, methanolysis, recycling, and also by a relatively new one - biodegradation. More and more attention is given to new approaches to waste disposal using biological methods for their degradation, including the use of bacteria $[4,5]$. It used to be believed that polyethylene does not lend itself to biodegradation, since it does not occur in nature. In recent years, more publications have appeared about organisms that have the ability to process, assimilate various types of polyethylene [6]. Japanese biologists have discovered a strain of bacteria capable of processing polyethylene [7]. They managed to isolate the bacterial strain Ideonella sakaiensis 201-F6, which hydrolyses polyethylene with the help of special enzymes. Bacteria can process a thin $(0.2 \mathrm{~mm})$ polyethylene film in six weeks at $30^{\circ} \mathrm{C}$. Organisms not only de- stroy the polymer, but also use it to generate energy. Bacteria hydrolyse the polymer with enzymes - resulting in the formation of terephthalic acid and ethylene glycol, further transformations of which are well described. It was found that the mold fungus Penicillium simplicissimum is capable of partially utilizing polyethylene preliminarily treated with nitric acid in three months [8]. With the help of fluorescence and scanning microscopy, it was found that the growth of the bacterium Nocardia asteroides occurs on the polyethylene surface with its degradation for 4-7 months [9]. Inhabitants of the Indian moth's (Plodia interpunctella) intestine can decompose $100 \mathrm{mg}$ of polyethylene in eight weeks [10].

The possibility of using a bee moth (Galleria mellonella Linnaeus, 1758) for the biodegradation of polymeric waste presents a new method in the environmental recycling of solid domestic waste. For the first time in 2017, Spanish scientists reported the ability of G. mellonella to process polyethylene. Researchers found that 100 larvae in 12 hours processed $92 \mathrm{mg}$ of polyethylene [11]. At the same time, the features of biodegradation of different types of polyethylene by $G$. mellonella larvae have not been fully studied to date.

It is assumed that bee moth larvae were able to process polyethylene because it is similar to their usual food. Hatched larvae of $G$. mellonella feed first with honey, then beeswax and bee bread, consisting of a mixture of organic substances [12]. The composition of the wax includes the limiting hydrocarbons forming carbon bonds $\mathrm{C}-\mathrm{C}$, similar to those found in the structure of polyethylene. At the same time, it should be noted that often pathogenic microscopic fungi affecting bee hives can enter their organisms together with wax [13].

Objective of this research is to evaluate the processes of biodegradation by $G$. mellonella larvae depending on the type of polyethylene. 


\section{Materials and Methods}

The object of the study were: various types of polyethylene, found in the structure of municipal solid waste.

The subject of the study was a bee moth (G. mellonella) and the ability of its larvae to biodegradation of polyethylene. Cocoons with bee moth pupae $(n=200)$ were obtained from the experimental apiary of the Institute of Ecology and Nature Management of Kazan (Volga region) Federal University. From the pupae under the experimental conditions, adult moths and, subsequently, larvae were obtained.

The types of polyethylene samples were determined on the FT801 IR Fourier spectrometer (Simex Analytical Equipment, Russia), the results were processed using the Ekoaudit LLC database designed for obtaining, processing and identification of IR spectra. In the course of the study, a bioreactor was designed to produce bee moth larvae and cages for experimental studies.

Larval health indicators (mobility, melanization, survival) were assessed according to the previously described procedure [14] The weight of larvae was measured on an analytical scale DV215CD Discovery (Ohaus, Switzerland). To visualize and take into account changes in the larvae's outer covers, a digital USB microscope DigiMicro Prof (DigiMicro, China) was used, with the MicroCapture Pro Version 2.2 software. For microscopic studies, the Biomed-3 microscope (BioMed Service, Russia), the trinocular, with the "Digital Camera for Microscope DCM310 (USB2.0)" imaging adapter and the "ScopePhoto 3.0" software were used.

The degree of biodegradation of polyethylene samples was estimated from the change in their mass (mg), as well as the number (unit) and area $\left(\mathrm{mm}^{2}\right)$ of holes formed (points of feeding) on them. Determination of the mass of polyethylene samples was carried out by weighing them on analytical scales. To determine the number and area of holes formed, the sample was scanned on a Laser Jet M1132 MFP (HPInc).

To reveal preferences of bee moth larvae in eating a particular type of polyethylene, the results were statistically processed using a single-factor analysis of variance (ANOVA). Differences between the groups were considered significant at $\mathrm{p}<0.05$.

\section{Results and Discussion}

\subsection{The Variety of Types of Polyethylene Samples in the Structure of Municipal Solid Waste}

At the first stage of the study, 27 samples of polyethylene (Figure 1 ), commonly found in the structure of municipal solid waste, were selected. The samples were selected widely represented in the structure of municipal solid waste in the form of containers for various purposes. These are bags, films and other packing material, some of which are bags used in the retail chains "Bahetle", "Magnit", "Edelweis", "Aisha", "Vprok", as well as packages for food and non-food products.
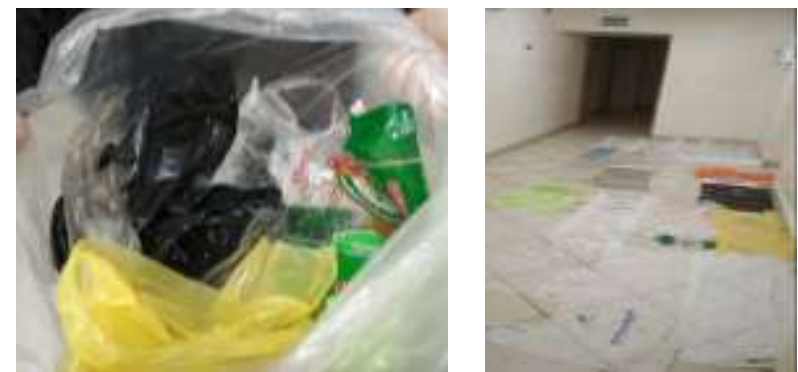

Fig. 1:. Samples of polyethylene used in the study

All the samples of polyethylene were subjected to IR Fourier spectrometry (Fig. 2). The description, characteristics, dimensions and weight of the samples are presented in Table 1. Among the polyethylene samples studied, the greatest amount is represented by polyethylene for food products, $29.62 \%$ ( 8 of 27 ), $11 \%$ are samples for transportation of food products (3 of 27), 11\% - an oilcloth package ( 3 of 27 ) and $7.4 \%$ ( 2 of 27 ) for storing paper towels. The remaining samples of polyethylene are presented in a single specimen and amounted to $2.7 \%$.

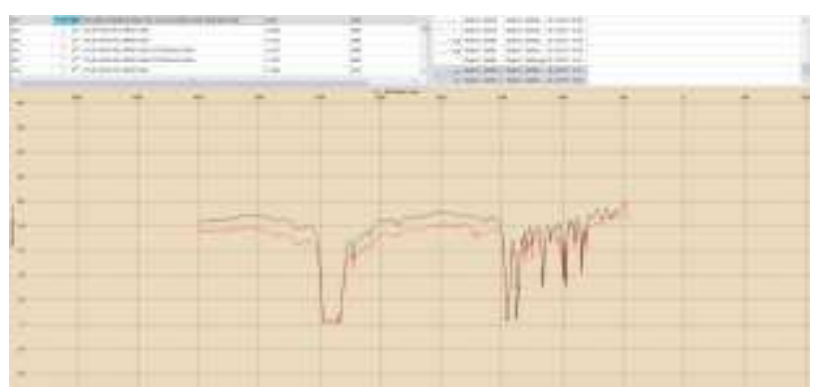

Fig. 2:. IR Fourier spectrometry of a polyethylene sample (example)

Table 1:. Characteristics of the types of polyethylene samples used in the study

\begin{tabular}{|c|c|c|c|c|}
\hline $\begin{array}{l}\text { sample No. } \\
\text { (n-quantity, } \\
\text { pc.) }\end{array}$ & $\begin{array}{l}\text { Type of polyethylene by IR spectrometric analysis and the } \\
\text { percentage of coincidence }\end{array}$ & Purpose of use & $\begin{array}{l}\text { Total area, } \\
\mathrm{cm}^{2}\end{array}$ & $\begin{array}{l}\text { Total } \\
\text { weight, } \\
\text { mg }\end{array}$ \\
\hline $1(\mathrm{n}=1)$ & $64,5 \%$ cta 87 fo 470 polypropylene & Food storage & 1100 & 5280 \\
\hline $2(n=1)$ & $51,5 \%$ cta 87 co 475 polypropylene ground cover fill & Food storage & 360 & 1737 \\
\hline $3(n=1)$ & $\begin{array}{l}60 \% \text { amaco/olefin (amaco of yarn) yel } 22.5 \text { u polypropylene } \\
\text { nbs-ho } 256\end{array}$ & Food storage & 896 & 4652 \\
\hline $4(n=1)$ & $\begin{array}{l}\text { 81,1\% phillips/olefin (marvess) tow } 18.4 \mathrm{u} \text { polypropylene } 3 \mathrm{den} \\
\text { nbs-f0249 }\end{array}$ & Paper towel storage & 800 & 3000 \\
\hline $5(n=1)$ & $65,6 \%$ parvan 4550, f.n. 3519 & Paper towel package & 1466 & 8352 \\
\hline $6(n=1)$ & $\begin{array}{l}48 \% \text { calcium carbonate, } 85 \% \text { concentrate carbonic acid, calci- } \\
\text { um salt }\end{array}$ & Food transportation & 3500 & 6655 \\
\hline $7(n=1)$ & $62,3 \%$ unbranched polyethylene, selfrein forced lupolen $6021 \mathrm{~d}$ & $\begin{array}{l}\text { Transportation of clothes from a } \\
\text { dry cleaner }\end{array}$ & 5684 & 11436 \\
\hline $8(n=1)$ & $62,3 \%$ astro turf / polypropylene green / std 416 & Shoes transportation & 2666 & 1700 \\
\hline $9(n=1)$ & $68 \%$ escorene ld- 105 & Food transportation & 2886 & 5250 \\
\hline $10(n=1)$ & $41,4 \%$ sealite 43 , f.n. 3679 & Food transportation & 3744 & 16600 \\
\hline $13(n=3)$ & $62,7 \%$ cta 87 co 473 polypropylene primary carpet backing & Cigarette wrapping film & 1619 & 4280 \\
\hline $14(n=4)$ & $77,9 \%$ petrothene $\operatorname{lr} 734$ & Food storage & 9048 & 5640 \\
\hline $15(n=1)$ & $62 \%$ armodur transpatent & MSW storage and transportation & 4602 & 2310 \\
\hline $16(n=2)$ & $74,9 \%$ cta 87 eo 398 olefin (polypropylene) & File for stationery & 2852 & 2790 \\
\hline $17(\mathrm{n}=1)$ & $69,7 \%$ unbranched polyethylene, selfrein forced lupolen $6021 \mathrm{~d}$ & Package of various items & 2028 & 3420 \\
\hline
\end{tabular}




\begin{tabular}{|l|l|l|l|}
\hline $18(\mathrm{n}=5)$ & $71 \%$ linear polyethylene hostalen gf 4750 & AIRplus air package & 2280 \\
\hline $19(\mathrm{n}=1)$ & $68,7 \%$ vybar 260 & Oilcloth package & 5050 \\
\hline $20(\mathrm{n}=2)$ & $74,7 \%$ petrothene lr 734 & Food storage & 7790 \\
\hline $21(\mathrm{n}=1)$ & $64,9 \%$ escorene ld 151 cf 1 & Oilcloth package & 2440 \\
\hline $22(\mathrm{n}=5)$ & $74,7 \%$ cta 87 ao 461 polyethylene laminated to craft paper & ZIP LOCK package & 6910 \\
\hline $23(\mathrm{n}=1)$ & $77,3 \%$ plastic bag & Oilcloth package & 990 \\
\hline $24(\mathrm{n}=1)$ & $82,9 \%$ cta 87 eo 398 olefin (polypropylene) & Packaging bag & 1800 \\
\hline $25(\mathrm{n}=1)$ & $73,8 \%$ poly(ethylene) & Food storage & 12600 \\
\hline $26(\mathrm{n}=1)$ & $73,2 \%$ a-c 6 & Food storage & 768 \\
\hline $27(\mathrm{n}=6)$ & $54,2 \%$ npe 953 & Food storage & 672 \\
\hline Total & \multicolumn{3}{|l|}{} \\
\hline
\end{tabular}

Based on bivariate analysis, multiple pregnancy, menopause, smoking, hyperglycemia, hypertension and hyperlipidemia were more prevalent among cases $(\mathrm{P}<0.001$ for all). However, the results suggested no significant difference in taking OCPs between cases and controls (table 1 The largest number of polyethylene samples also had the largest area and weight. The area of food package polyethylene was 4.6 $\mathrm{m}^{2}$, and weight $27,459 \mathrm{mg}$. The area of polyethylene waste for food transportation was $1.013 \mathrm{~m}^{2}$ and had a mass of $21,850 \mathrm{mg}$, the area of the oilcloth package was $0.563 \mathrm{~m}^{2}$ and the weigh $26,260 \mathrm{mg}$. It is interesting that some samples of polyethylene with its share of not more than $3 \%$ of the total number of packages had a large area and weight. For example, polyethylene for transportation of various items had an area of $0.568 \mathrm{~m}^{2}$ and weighted $17,960 \mathrm{mg}$.

\subsection{Cultivation of $G$. mellonella}

Three bioreactors were designed and installed to grow and maintain a moth culture. The bioreactor is a plastic cube with a lid, with dimensions: height $-31 \mathrm{~cm}$, width $-23 \mathrm{~cm}$, length $-28 \mathrm{~cm}$, volume: $19,964 \mathrm{~cm}^{3}\left(0.02 \mathrm{~m}^{3}\right)$. To provide air circulate holes of 10 x $5 \mathrm{~cm}$ covered with a metal net with the help of Scotch tape (the mesh cells did not exceed $0.2 \times 0.2 \mathrm{~cm}$ in size) were cut out on the lid and on one wall.

In each bioreactor, the feed mixture was added in a proportion of 1:3:3 - bee bread: beeswax: slumgum and 100 cocoons with pupae of G. mellonella (Figure 3). Within 52 days, the entire cycle of development of the wax moth passed through the bioreactors. It has been established that $G$. mellonella is successfully cultivated under artificial conditions of the bioreactor in low light, at a temperature of $25-30^{\circ} \mathrm{C}$ and in humidity of $67-80 \%$.
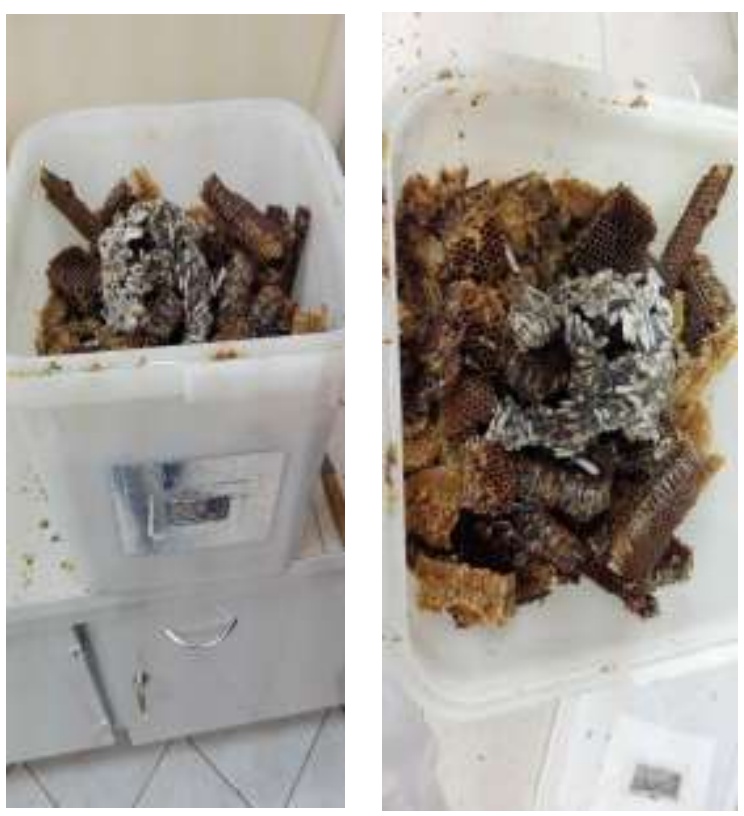

Fig. 3:. Bioreactor with fodder and pupae of G. mellonella

\subsection{Polyethylene Biodegradation Experiment}

One of the above bioreactors was filled with all the polyethylene samples listed in Table 1. The experimental conditions were the same as for the cultivation of a large bee moth. The experiment lasted for 90 days, during which biodegradation of various types of polyethylene was observed. To estimate the extent of biodegradation, the mass of polyethylene samples, the number and the area of the formed holes were measured in the course of the experiment.

The development cycle of G. mellonella in the experimental bioreactor continued, similar to that in the bioreactor free of polyethylene. Despite the sufficient amount of food in the bioreactor, large bee moth's larvae also ate polyethylene of all the types presented (Figure 4).

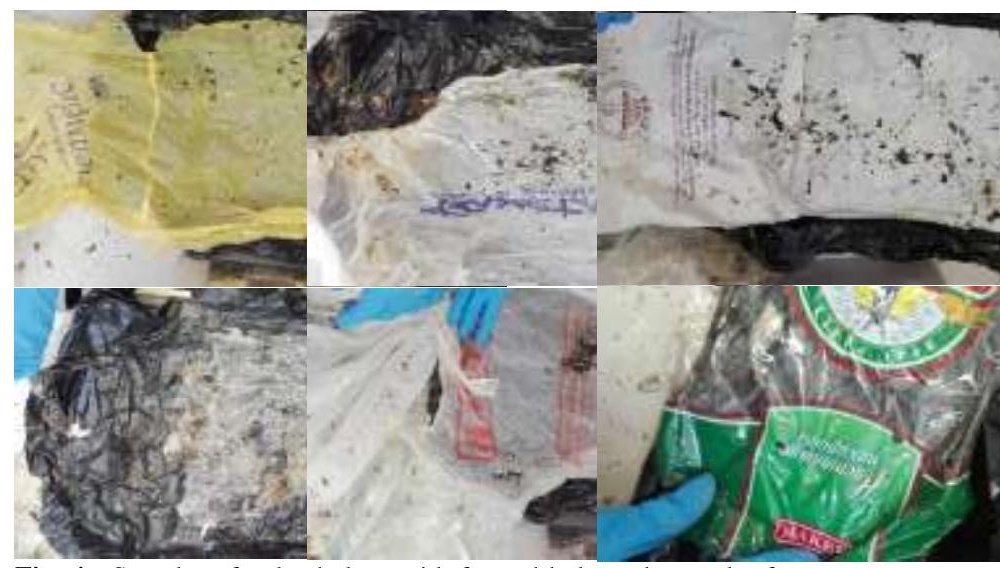

Fig. 4:. Samples of polyethylene with formed holes - the result of a process of biodegradation by $G$. mellonella larvae

When assessing the degree of biodegradation, it was found that holes in the polyethylene samples of different sizes formed $5.3 \pm 2.4$ - 28.7 \pm 9.4 units/day and $54.8 \pm 12.6$ - $1867.8 \pm 38.6$ $\mathrm{mm} 2 /$ day, and the mass of polyethylene samples, depending on the type, decreased on average by $1.5 \pm 0.5-51.0 \pm 6.5 \mu \mathrm{g} / \mathrm{day}$. It should be noted that polyethylene in the body of bee moth larvae decomposes to ethylene glycol [11], which confirms the biodegradation process.

\subsection{Assessment of Health Indicators of Larvae and Ima- gos of G. Mellonella}

The experiment revealed that $84.8 \pm 8.3 \%$ of the larvae in the bioreactor with polyethylene remained alive, which does not differ significantly from the indicator in the bioreactor without polyethylene $-85.8 \pm 7.9 \%(p>0.05)$. Consequently, eating polyethylene does not affect the survival rate of larvae. The average mass of live larvae in the pre-pupal stage was noted at the level of $182.4 \pm 26.3 \mathrm{mg}$ and $188.7 \pm 28.2 \mathrm{mg}$, respectively ( $>0.05$ ). It follows that polyethylene does not affect the growth rate of larvae. Most individuals from both bioreactors were active without stimulation, single individuals showed activity after stimulation. The processes of melanization of the outer cover of $G$. mellonella larvae were not detected (Fig. 5a). However, larvae with the process- 
es of orange pigmentation (Figure 5b), which persisted in adult individuals were found in the bioreactor with polyethylene (Fig. 5c).

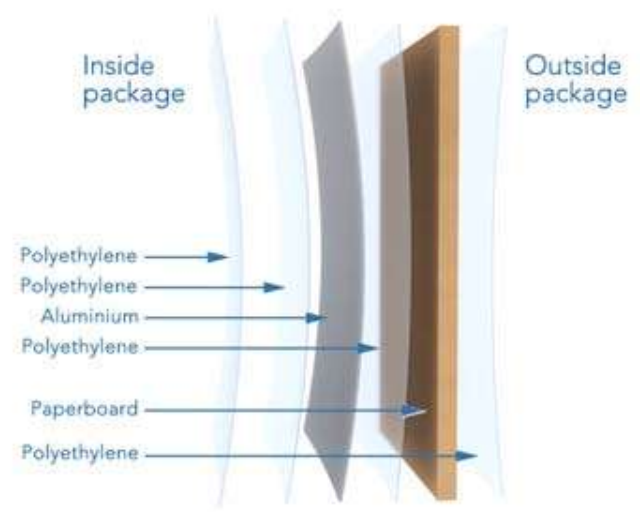

Fig. 5: G. mellonella after eating orange polyethylene: larvae without pigmentation (a), larvae (b) and imago (c) with pigmentation

Thus, the conducted experiments indicate that there is no toxic effect of polyethylene on the investigated health indicators of $G$. mellonella larvae. The noted processes of orange pigmentation are most likely due to eating polyethylene with such a dye.

\section{Conclusion}

Among the polyethylene samples studied in the structure of municipal solid waste, the largest number is represented by polyethylene for food storage (29.6\%), for transportation of food products $(11.0 \%)$, and oilcloth package $(11.0 \%)$. When assessing the degree of biodegradation, it was found that holes in the polyethylene samples of different sizes formed 5.3 $\pm 2.4-28.7 \pm 9.4$ units/day and $54.8 \pm 12.6-1867.8 \pm 38.6 \mathrm{~mm} 2 /$ day, and the mass of polyethylene samples, depending on the type, decreased on average by $1.5 \pm 0.5$ $51.0 \pm 6.5 \mu \mathrm{g} /$ day. Polyethylene in the body of bee moth larvae decomposes to ethylene glycol, which confirms the biodegradation process. The obtained results of survival, mobility, weight gain and melanization indicate the absence of negative health effects of larvae from eating polyethylene. However, there were noted processes of orange pigmentation, which are most likely due to eating polyethylene with such a dye.

\section{Acknowledgement}

The work is performed according to the Russian Government Program of Competitive Growth of Kazan Federal University. The authors express their gratitude to Ruslan Sergeevich Kuzmin (Ekoaudit, Kazan, Russia) for assisting in the IR Fourier spectrometry of polyethylene samples.

\section{References}

[1] Bilalov F., Skrebneva L., Nikitin O., Shuralev E.A., Mukminov M. Seasonal variation in heavy-metal accumulation in honey bees as an indicator of environmental pollution. Research Journal of Pharmaceutical, Biological and Chemical Sciences, 2015, 6(4): 215-221

[2] Gindullin A.I., Shamilova T.A., Gindullina D.A., Tremasov M.Y., Ivanov A.V., Ivanov A.A., Chernov A.N., Mukminov M.N., Shuralev E.A. Influence of probiotics spas and biosporin at t-2 toxication of broiler chickens. Research Journal of Pharmaceutical, Biological and Chemical Sciences, 2015, 6(4): 2142-2150

[3] Bagriantseva E.P. Mechanism of biodegradation of composite packaging films by soil microorganisms. Consumer cooperation, 2015, 3 (50): 52-56
[4] Matrosova L.E., Tremasov M.Ya., Cherednichenko Yu.V., Matveeva E.L., Ivanov A.A., Mukminov M.N., Ivanov A.V., Shuralev E.A. Efficiency of specific biopreparations in organic waste management. Indian Journal of Science and Technology, 2016, 9(18), doi: $10.17485 / \mathrm{ijst} / 2016 / \mathrm{v} 9 \mathrm{i} 18 / 93762$

[5] Elamin A.A., Steinicke S., Oehlmann W., Braun Y., Wanas H., Shuralev E.A., Huck C., Maringer M., Rohde M., Singh M. Novel drug targets in cell wall biosynthesis exploited by gene disruption in Pseudomonas aeruginosa. PLoS ONE, 2017, 12(10): e0186801, doi: 10.1371/journal.pone.0186801

[6] Soprunova O.B., Leontieva (Kashirskaia) A.O. Change in the strength properties of polyethylene during exposure in the model experiments with destructing microorganisms. Bulletin of Voronezh Universiteta University, Series: Chemistry. Biology. Pharmacy, 2017, 2: 93-98

[7] Yoshida S., Hiraga K., Takehana T., Taniguchi I., Yamaji H., Maeda Y., Toyohara K., Miyamoto K., Kimura Y., Oda K. A bacterium that degrades and assimilates poly(ethylene terephthalate). Science, 2016, 351(6278): 1196-1199, doi 10.1126/science.aad6359

[8] Restrepo-Flórez J.-M., Bassi A., Thompson M.R. Microbial degradation and deterioration of polyethylene - a review. Int. Biodeterior Biodegrad., 2014, 88: 83-90, doi: 10.1016/j.ibiod.2013.12.014

[9] Bonhomme S., Cuer A., Delort A.-M., Lemaire J., Sancelme M., Scott G. Environmental biodegradation of polyethylene. Polymer Degradation and Stability, 2003, 81(3): 441-452, doi: 10.1016/S0141-3910(03)00129-0

[10] Yang J., Yang Y., Wu W. M., Zhao J., Jiang L. Evidence of polyethylene biodegradation by bacterial strains from the guts of plastic-eating waxworms. Environ Sci Technol., 2014, 48(23): 1377613784, doi: 10.1021/es504038a

[11] Bombelli P., Howe C.J., Bertocchini F. Polyethylene biodegradation by caterpillars of the wax moth Galleria mellonella. Curr Biol., 2017, 27(8): R292-R293, doi: 10.1016/j.cub.2017.02.060

[12] Osokina A.S., Kolbina L.M., Gushchin A.V. Influence of feeding and storage conditions on the growth of large bee moth larvae $(\mathrm{Gal}-$ leria mellonella L.). Achievements of science and technology of agroindustrial complex, 2016, 30 (7): 88-92

[13] Yumangulova G.M., Semenov E.I., Potekhina R.M., Mukminov M.N., Shuralev E.A. Effect of abiotic stressors on T-2-producing environmental isolates of Fusarium sporotrichioides. Journal of Pharmacy Research, 2017, 11(10): 1226-1229

[14] Gaidai D.S., Gaidai E.A., Makarova M.N. Large bee moth larvae (Galleria mellonella) as a model object for the study of new drugs. International Veterinary Journal of Veterinary Medicine, 2017, 2: $82-90$ 